\title{
Phenytoin (diphenylhydantoin) treatment of massive digoxin overdose
}

\author{
Barry H. Rumack, Robert R. Wolfe, and Hans Gilfrich \\ From the Departments of Pediatrics and Clinical Pharmacology, The B.F. Stolinsky Research Laboratories, \\ The Pediatric Cardiology Service, The University of Colorado Medical Center, Denver, Colorado; and The \\ Poison Control Center, Denver General Hospital, Denver, Colorado, U.S.A.
}

\begin{abstract}
A I7-year-old patient attempted suicide with a massive digoxin overdose. Peak serum digoxin level was 35 $\mathrm{ng} / \mathrm{ml}$. Half-life of digoxin was 13 hours which is in contrast to the usual therapeutic half-life of approximately 36 hours. Pronounced hyperkalaemia, peaking at $8 \cdot 2 \mathrm{mEq} / \mathrm{l}$., was noted 14 hours after ingestion. Control of toxic symptoms was achieved with small doses of diphenylhydantoin. It is suggested that the usual initial treatment of this overdose with potassium as suggested in many sources is inappropriate.
\end{abstract}

Therapeutic manoeuvres for the treatment of massive single digoxin overdose have been based on extensions of principles applicable to the treatment of chronic digoxin toxicity. Standard reference sources usually available to physicians who treat poisonings suggest as appropriate treatment atropine, potassium salts, magnesium salts, procainamide, quinidine, sodium salts of EDTA, phenytoin (diphenylhydantoin, DPH), pacemakers, lactones, and propranolol (Gleason et al., 1969; Goodman and Gilman, 1970; Dreisbach, 1971). A widely consulted source concludes with the sentence: 'Probably potassium is the most useful agent' (Gleason et al., 1969). Recent articles suggest that the practice of early institution of potassium therapy should be questioned (Smith and Willerson, I97I; Citrin, Stevenson and O'Malley, 1972) as deaths have been reported with refractory hyperkalaemia. Hyperkalaemia to $9.8 \mathrm{mEq} / \mathrm{l}$. was reported in one patient who died with a plasma digoxin level of $42 \mathrm{ng} / \mathrm{ml}$ (Smith and Willerson, I97I). Two survivors with digoxin levels of $19.9 \mathrm{ng} / \mathrm{ml}$ and $17 \mathrm{ng} / \mathrm{ml}$ also demonstrated hyperkalaemia of $6.8 \mathrm{mEq} / 1$. and $8.4 \mathrm{mEq} / 1$., respectively (Citrin et al., 1972). Reported here is a surviving patient with a massive digoxin overdose and blood levels of $35 \mathrm{ng} / \mathrm{ml}$ when first sampled I $2 \frac{1}{2}$ hours after ingestion, who had carefully documented potassium levels throughout her course. Calculation of half-life for digoxin gave a result onethird of that reported with therapeutic digoxin
(Goodman and Gilman, 1970). A suggested treatment method using low doses of phenytoin is discussed.

\section{Case report}

A 17-year-old despondent female was admitted to the referring hospital $5 \frac{1}{2}$ hours after ingesting $17(400 \mathrm{mg})$ meprobamate tablets and $50(0.25 \mathrm{mg})$ digoxin tablets. She had previously been healthy and was not taking any medications. At the time of her initial evaluation the blood pressure was $104 / 50 \mathrm{mmHg}$, temperature was $34.8^{\circ} \mathrm{C}$, and monitoring revealed a bradycardia of $40 /$ minute with varying first, second, and third-degree block (Fig. I). Chest $x$-ray showed an aspiration pneumonia. Arterial blood gases at that time were $\mathrm{PCO}_{2}$ $60 \mathrm{mmHg}, \mathrm{Po}_{2} 38 \mathrm{mmHg}$, and $\mathrm{pH} 7 \cdot 18$. Blood urea, serum creatinine, and urinalysis were all normal. Because the tidal volume was less than $200 \mathrm{ml}$ she was placed on a respirator. Thirteen hours after ingestion arterial $p \mathrm{H}$ was $7 \cdot 25$, serum Na was $126 \mathrm{mEq} / 1$., and $\mathrm{K}$ was $8.0 \mathrm{mEq} / \mathrm{l}$. The patient received a total of $20 \mathrm{mEq}$ of potassium cloride before she was transferred to the regional treatment centre because of the hyperkalaemia and deepening coma. No further potassium was given until 72 hours after ingestion. The plasma potassium levels throughout the course are shown in the Table. A total of 7 doses of phenytoin $(25 \mathrm{mg} /$ dose intravenously) were given over 36 hours as required to maintain a ventricular rate greater than $40 /$ minute. Twenty-seven hours after ingestion her blood pressure was $80 / 60$ $\mathrm{mmHg}$ and the electrocardiogram showed complete heart block with a ventricular rate of 50 beats/minute. 


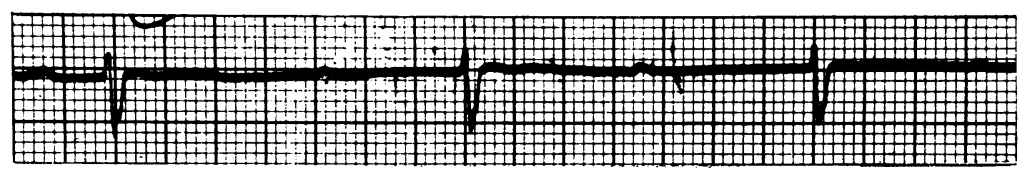

a

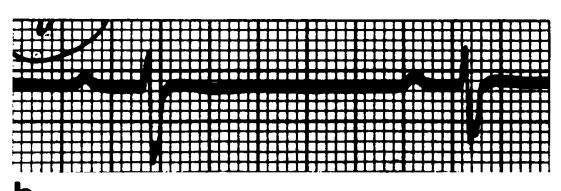

b

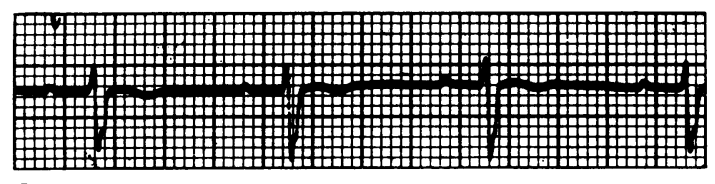

C

FIG. I Serial electrocardiograms (all lead $V_{I}$ ). a) On admission to referring hospital before treatment: complete heart block. b) 24 hours later, on admission to treatment centre: complete heart block. c) 92 hours after ingestion: normal sinus rhythm.

A transvenous pacemaker was inserted and placed on standby, but was never used. A His bundle recording was obtained during the procedure which demonstrated complete heart block with a junctional pacemaker. Bicarbonate therapy was required continuously for 48 hours to correct her acidosis. At the end of this time the meprobamate level was $0.2 \mathrm{mg} / 100 \mathrm{ml}$. Heart rate then was $48 /$ minute but gradually rose and remained about $72 /$ minute by 98 hours after ingestion.

Plasma digoxin concentration measurements were performed by radio-immunoassay using the technique decribed in recent publications (Smith, Butler, and Haber, 1969, 1970). The half-life of plasma digoxin concentration decay was approximated using least square regression analysis (Fig. 2).

\section{Discussion}

This patient had ingested a massive $12.5 \mathrm{mg}$ dose of digoxin. The first blood sample, drawn $12 \frac{1}{2}$ hours

TABLE Plasma potassium values

\begin{tabular}{ll}
\hline Hours after ingestion & $\begin{array}{l}\text { Potssium } \\
(m E q / l .)\end{array}$ \\
\hline $5 \frac{1}{2}$ & $5 \cdot 6$ \\
7 & $6 \cdot 9$ \\
9 & $7 \cdot 3$ \\
12 & $7 \cdot 2$ \\
13 & $8 \cdot 0$ \\
14 & $8 \cdot 2$ \\
$20 \frac{1}{2}$ & $7 \cdot 2$ \\
$29 \frac{1}{2}$ & $5 \cdot 6$ \\
33 & $4 \cdot 8$ \\
50 & $4 \cdot 2$ \\
74 & $3 \cdot 6$ \\
\hline
\end{tabular}

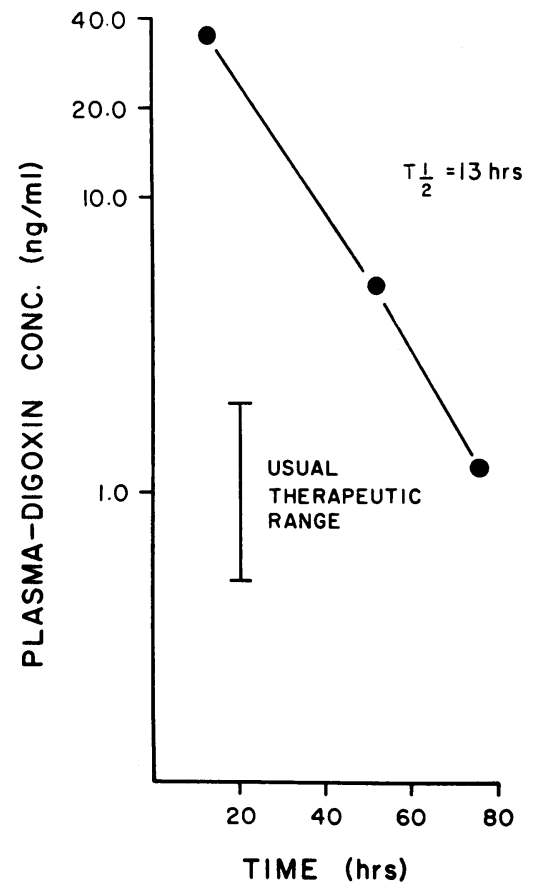

FIG. 2 Plasma digoxin concentrations are shown on the vertical axis, time after ingestion on the horizontal. The plot is semilogarithmic. The half-time $\left(T \frac{1}{2}\right)$ and the usual therapeutic ranges are indicated. 
after ingestion, had a plasma digoxin level of $35 \mathrm{ng} / \mathrm{ml}$ by radioimmunoassay. This is the highest level reported in a surviving patient. A $12 \frac{1}{2}$-hour period has been shown to produce adequate kinetic equilibrium between blood and tissue after an orally administered dose of digoxin within the therapeutic range (Doherty, Perkins, and Mitchell, I96I). After this period of distribution the onset of slow exponential decline of tritiated digoxin with a mean halflife of 31 hours is reported in humans with normal renal function (Doherty, 1970). In this case a halflife of plasma digoxin decay of 13 hours was observed until the normal therapeutic range of digoxin concentration in plasma was achieved (Fig. 2). This finding is in agreement with previous results (Smith and Willerson, I97I; Hobson and Zettner, 1973). Though there have been several previous reports of larger numbers of digoxin tablets ingested, few have quoted plasma levels; the one patient with levels in the range achieved in our case died (Smith and Willerson, I97I). Fatal cases have consistently shown higher serum potassium levels than non-fatal cases of digoxin overdose (Smith and Willerson, 1971).

Previous experience has indicated that younger and healthier patients rarely have ectopic activity with cardiac glycoside intoxication. This also has been found to be true in an overdose situation (Smith and Willerson, I971). Though potassium can suppress ectopic activity, this has been reported to occur rarely when no loading dose of potassium is given (Zellis et al. 1970). Potassium has also been reported to increase $\mathrm{AV}$ block and affects the junctional tissue transmembrane potential in a manner similar to digitalis toxicity (Mason et al., I97I). It seems then that potassium should not be used in the treatment of patients with acute single cardiac glycoside overdose with coexistent high grade heart block unless the serum potassium is below the normal range. Our patient clearly showed hyperkalaemia even in the face of massive alkalinizing therapy. The acidosis known to occur with meprobamate toxicity may have initially contributed to the hyperkalaemia, but the potassium levels were independent of the acidosis and meprobamate blood levels.

Successful treatment was reported with atropine in a patient overdosed with digoxin (Navab and Honey, 1967) but serum levels of digoxin were not available. In this case atropine restored atrial activity and increased the heart rate from 22 to $25 /$ minute to $60 /$ minute. Serum potassium at the time of greater digoxin effect was $7.9 \mathrm{mEq} / \mathrm{l}$. but fell to $4 \cdot 2 \mathrm{mEq} / \mathrm{l}$. with re-establishment of urine flow. Potassium administration was required late in the course (which we also found necessary in our patient) but was clearly contraindicated earlier in the course.

Phenytoin was first proposed in 1950 (Harris and Kokernot, 1950) for use in digitalis intoxication and is now widely used. Though several papers suggest that very large doses of phenytoin are necessary to overcome digitalis intoxication, we did not find this to be the case (Bashour et al., 1968). Our patient responded to $25 \mathrm{mg}$ of phenytoin when her digoxin blood level was at its peak. Repeated doses of phenytoin are known to improve AV conduction, resulting in greater atrial input to the ventricle (Mason et al., 1971). Our patient had complete heart block early in her course and phenytoin restored her to a first-degree block.

Massive overdose of cardiac glycosides should then be approached somewhat differently from chronic intoxication. Potassium should be avoided unless there is proven hypokalaemia. Phenytoin has specific effects on the high grade heart block often noted in this circumstance and is a reasonable first drug if this dysrhythmia is present. Atropine and other drugs used in the treatment of digitalis overdoses may be considered if patients prove refractory to supportive care with phenytoin. Dialysis should be considered for treatment of uncorrected acidbase or electrolyte imbalance but not as a means of removing significant amounts of tissue fixed cardiac glycoside. Half-life has been shown by us and by others to be shortened in massive overdose so that conservative supportive care should be the treatment of choice with careful attention to respiratory care, arrhythmias, cardiac output, and fluid therapy.

This case and the few others reported indicate that potassium, should not be the initial drug of choice as has been suggested in standard toxicology textbooks. Low dose phenytoin was dramatically effective in this case and should be used early in the treatment of acute digoxin overdose. Since phenytoin is a negative inotropic agent in a dose related manner, it seems rational to administer relatively low doses, and then assess the efficacy of this regimen.

Appreciation is expressed to Dr. Morris Radack, Yankton, South Dakota, for referral of this patient.

\section{References}

Bashour, F. A., Edmonson, R. E., Gupta, D. N., and Prati, R. (1968). Treatment of digitalis toxicity by diphenylhydantoin (Dilantin). Diseases of the Chest, 53, 263.

Citrin, D., Stevenson, I. H., and O'Malley, K. (1972). Massive digoxin overdose: observations on hyperkalemia and plasma digoxin levels. Scottish Medical fournal, 17, 275.

Doherty, J. E. (1970). The pharmacokinetics of tritiated digoxin. In Pharmacological and Clinical Significance of 
Pharmacokinetics. F. K. Schattauer, Stuttgart and New York.

Doherty, J. E., Perkins, W. H., and Mitchell, G. K. (I96I). Tritiated digoxin studies in human subjects. Archives of Internal Medicine, 108, 531.

Dreisbach, R. H. (1971). Handbook of Poisoning: Diagnosis and Treatment, 7 th ed. Lange, Los Altos, California.

Gleason, M. N., Gosselin, R. E., Hodge, H. C., and Smith, R. P. (1969). Clinical Toxicology of Commercial Products, 3rd ed. Williams and Wilkins, Baltimore.

Goodman, L. S., and Gilman, A. (1970). The Pharmacological Basis of Therapeutics, $4^{\text {th }}$ ed. Macmillan, New York.

Harris, A. S., and Kokernot, R. H. (1950). Effects of diphenylhydantoin sodium and phenobarbitol sodium upon ectopic ventricular tachycardia in acute myocardial infarction. American fournal of Physiology, 163, 505.

Hobson, J. D., and Zettner, A. (I973). Digoxin serum halflife following suicidal digoxin poisoning. Fournal of the American Medical Association, 223, 147.

Mason, D. T., Zellis, R., Lee, G., Hughes, J. L., Spann, J. F., and Amsterdam, E. A. (197I). Current concepts and treatment of digitalis toxicity. American fournal of Cardiology, 27, 546 .
Navab, F., and Honey, M. (1967). Self-poisoning with digoxin: successful treatment with atropine. British Medical fournal, 3, 660 .

Smith, T. W., Butler, V. P., Jr., and Haber, E. (1969). Determination of therapeutic and toxic serum digoxin concentrations by radioimmunoassay. New England fournal of Medicine, 281, 1212.

Smith, T. W., Butler, V. P., Jr., and Haber, E. (1970). Characterization of antibodies of high affinity and specificity for the digitalis glycoside digoxin. Biochemistry, 9, 331.

Smith, T. W., and Willerson, J. T. (197I). Suicidal and accidental digoxin ingestion. Circulation, 44, 29.

Zellis, R., Mason, D. T., Spann, J. F., Jr., and Braunwald, E. (1970). Effects of ventricular stimulation and potassium administration on digitalis-induced arrhythmias. American Fournal of Cardiology, 25, 428.

Requests for reprints to Dr. Barry H. Rumack, Department of Pediatrics, University of Colorado Medical Center, 4200 East Ninth Avenue, Denver, Colorado 80220 , U.S.A. 